Plant Tissue Cult. \& Biotech. 25(1): 13-20, 2015 (June)

$\overline{\text { PTC\&B }}$

\title{
Micropropagation of Orchid Carrying Knotted1-Like from Arabidopsis thaliana (Knat1) Gene
}

\section{Rindang Dwiyani*, Aziz Purwantoro", Ari Indrianto ${ }^{2}$ and Endang Semiarti $^{2}$}

Faculty of Agriculture, Udayana University, Denpasar (Bali), Indonesia

Key word: Knoted1-Like Arabidopsis thaliana (KNAT1) gene, Micropropagation

\begin{abstract}
s
KNOTED1-LIKE from Arabidopsis thaliana (KNAT1) gene keeps shoot apical meristem (SAM) in the meristematic state. The objective of the research was to investigate whether the function of KNAT1 gene in keeping plant cells under 'meristematic state' was functionally still work in the organ of the KNAT1 transformant. The transformant and WT plants were micropropagated, sliced and cut into some pieces, i.e. base of root, middle of root, root tip, a whole shoot, base of leaf, and leaf tip and planted in the New Phalaenopsis medium added with and without $5 \mu \mathrm{M} 2-\mathrm{iP}$ and $0.15 \mu \mathrm{M}$ NAA. The results show that cells of KNAT1 transformant were more meristematic compared to wild type plants as the organ produced more buds in micropropagation.
\end{abstract}

\section{Introduction}

KNOX (KNOTTED1-LIKE HOMEOBOX) genes are defined by homology to the Maize KNOTED1 (KN1) gene and are grouped in to two classes of gene based on sequence identity and conserve intron location (Bharathan et al. 1999 ; Reiser et al. 2000). Class 1 KNOX genes in Arabidopsis thaliana comprise of SHOOTMERISTEMLESS (STM), KNOTED-LIKE from Arabidopsis thaliana i.e. KNAT1, KNAT2 and KNAT6 genes (Semiarti et al. 2001) and keep shoot apical meristem (SAM) in the meristematic state (Barton 2001, Scofield et al. 2008). Scofield et al. (2008) proposed that during vegetative growth of Arabidopsis thaliana, STM gene is active and keeps the stem cell pool in the SAM, and the role of $S T M$ in keeping stem cell pool can only be substituted by overexpression of KNAT1 gene, but not with other KNOX genes.

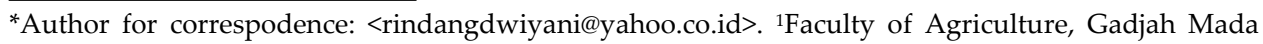
University, Yogyakarta, Indonesia. ${ }^{2}$ Faculty of Biology, Gadjah Mada University, Yogyakarta, Indonesia 
The role of the KNAT1 gene in keeping plant cell under meristematic state was examined in the current research by micropropagated orchid plants that carrying KNAT1 gene. The objective of the research was to investigate whether the function of KNAT1 gene in keeping plant cells under 'meristematic state' was functionally still work in the organ of the KNAT1 transformant. Yanal et al. (2005) proposed that KNOX protein in A. thaliana promotes biosynthesis of indegenous cytokinin of plants. While the role of cytokinin for shoot inducing in micropropagation was reported elsewhere. This could be explaine that the current research is required in order to answer that quisionable statement.

\section{Materials and Methods}

The research was conducted for 6 months during July, 2011 to January, 2012 at the Laboratory of Biotechnology, Faculty of Biology, Gadjah Mada University, Yogyakarta, Indonesia. Authors used orchid of Phalaenopsis amabilis and Vanda tricolor Lindl. that carrying KNAT1 gene. The KNAT1 transformant of P. amabilis was resulted from previous research of Agrobacterium-mediated transformation which was done by Sulastri Isminingsih, a Magister student at Faculty of Biology, Gadjah Mada University, Indonesia in 2004, while the KNAT1 transforman of $V$. tricolor Lindl. was resulted from Agrobacterium-mediated transformation which was done by Dwiyani, a part of Doctoral research at Department of Biotechnology, Gadjah Mada University, Indonesia in 2011. Both transformation ( $P$. amabilis and $V$. tricolor) used protocorm as target of transformation. Protocorms are yellow or green structures that appear when orchid seeds germinate. Procedures of those transformation are detailed in Isminingsih (2004) for P. amabilis and Dwiyani (2012) for $V$. tricolor. Due to limited number of transformant collection, so we used only 5 transformants for $P$. amabilis and 3 transformants for $V$. tricolor orchid. We also used wild Type plants (WT) for control. Those WT were collected from seedlings in which the seed sew at the same time with those of protocorms that were used for transformation. All plantlet used in this current research were steril (seedling from in vitro), so we did not require procedures of explant sterilization.

For P. amabilis orchid, plantlest of the transformant and WT were sliced and cut into some pieces, i.e. base of root, middle of root, root tip, a whole shoot, base of leaf, and leaf tip. Size of explant ranged between 5 and $15 \mathrm{~mm}$. Those slices of organ were planted in the New Phalaenopsis (NP) Medium (Islam et al. 1998) added with $5 \mu \mathrm{M}$ 2-iP and $0.15 \mu \mathrm{M}$ NAA, later this medium named Shoot Induction Medium (SIM). Those slices of organ were also planted in the NP

medium without any plant growth regulator (named NPO medium). Subculture was done every two weeks by moving the plantlet on the same type of medium 
in where they were planted first. The number of buds produced per explant was observed.

For $V$. tricolor orchid, plantlets of both transformant and WT were sliced into a whole shoot, a whole root, base of leaf and leaf tip. Explant size was $3 \mathrm{~mm}$ to 8 $\mathrm{mm}$. These slices of organ were planted at the same medium of those for $P$. amabilis as mentioned before. The number of buds per explant was observed. However, due to contamination, we have no data for root anf leaf tip.

\section{Results and Discussion}

Phalaenopsis amabilis: An average number of buds produced from each type of explant at 9 weeks after planting can be seen at Table 1. Buds were produced by all explant of transformant on SIM, but only explant of shoot produced buds on NPO medium. However, no buds were produced by WT explants on NPO, while an average of 1 bud was produced on SIM from explant of shoot and leaf base.

Table 1. The number of buds produced by each type of explan of WT plant and KNAT1 transformant at 9 weeks after planting on culture media.

\begin{tabular}{lcccc}
\hline \multirow{2}{*}{ Types of explant } & \multicolumn{2}{c}{ NPO Medium } & \multicolumn{2}{c}{ SIM } \\
\cline { 2 - 5 } & WT & KNAT1 transformant & WT & KNAT1 transformant \\
\hline Root base & 0 & 0 & 0 & 28 \\
Middle of root & 0 & 0 & 0 & 5 \\
Root tip & 0 & 0 & 0 & 1 \\
Leaf base & 0 & 0 & 1 & 11 \\
Leaf tip & 0 & 0 & 0 & 0 \\
Shoot & 0 & 4 & 1 & 23 \\
\hline
\end{tabular}
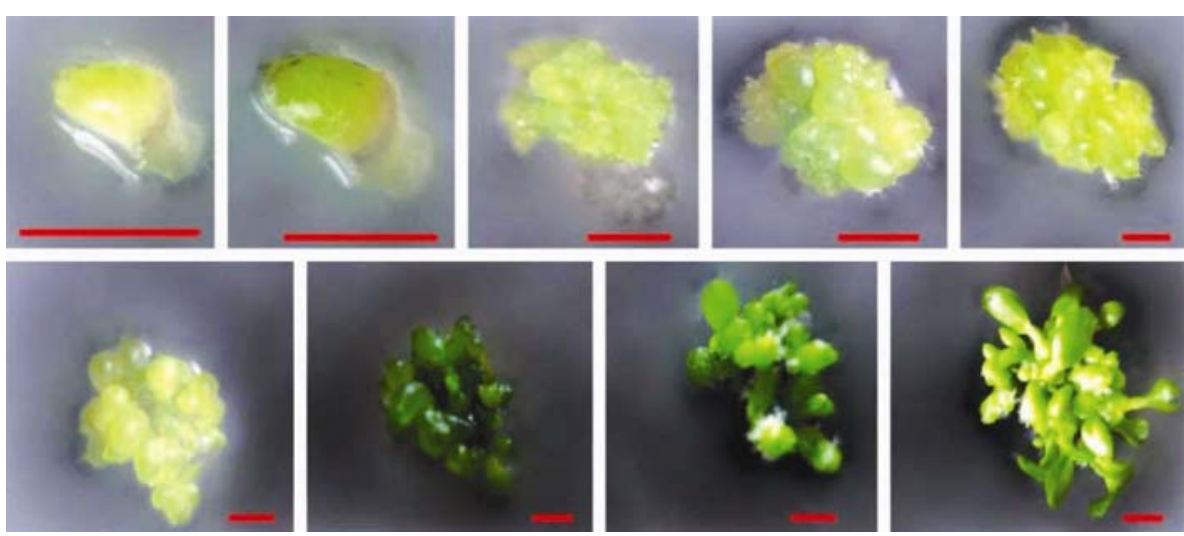

Fig. 1. Development and growth of an explant of root base from KNAT1 transformant planted on SIM. Above, from left to right: 1, 2, 3, 4 and 6 weeks after planting; below, from left to right : 7, 9, 10 and 12 weeks after planting. Bar $=5 \mathrm{~mm}$. 


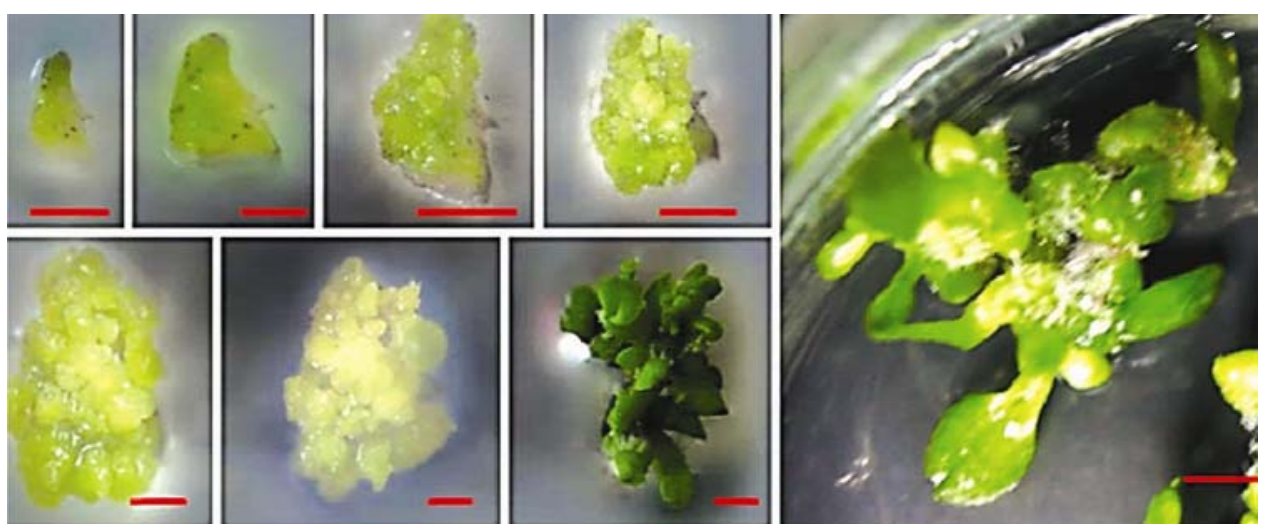

Fig. 2. Development and growth of an explant of leaf base from KNAT1 trabsformant planted on SIM. Above, from left to right: 1, 2, 3, and 4 weeks after planting; below, from left to right : 7, 9, and 10 weeks after planting; the biggest picture in the right side is at 12 weeks after planting. Bar $=5 \mathrm{~mm}$.
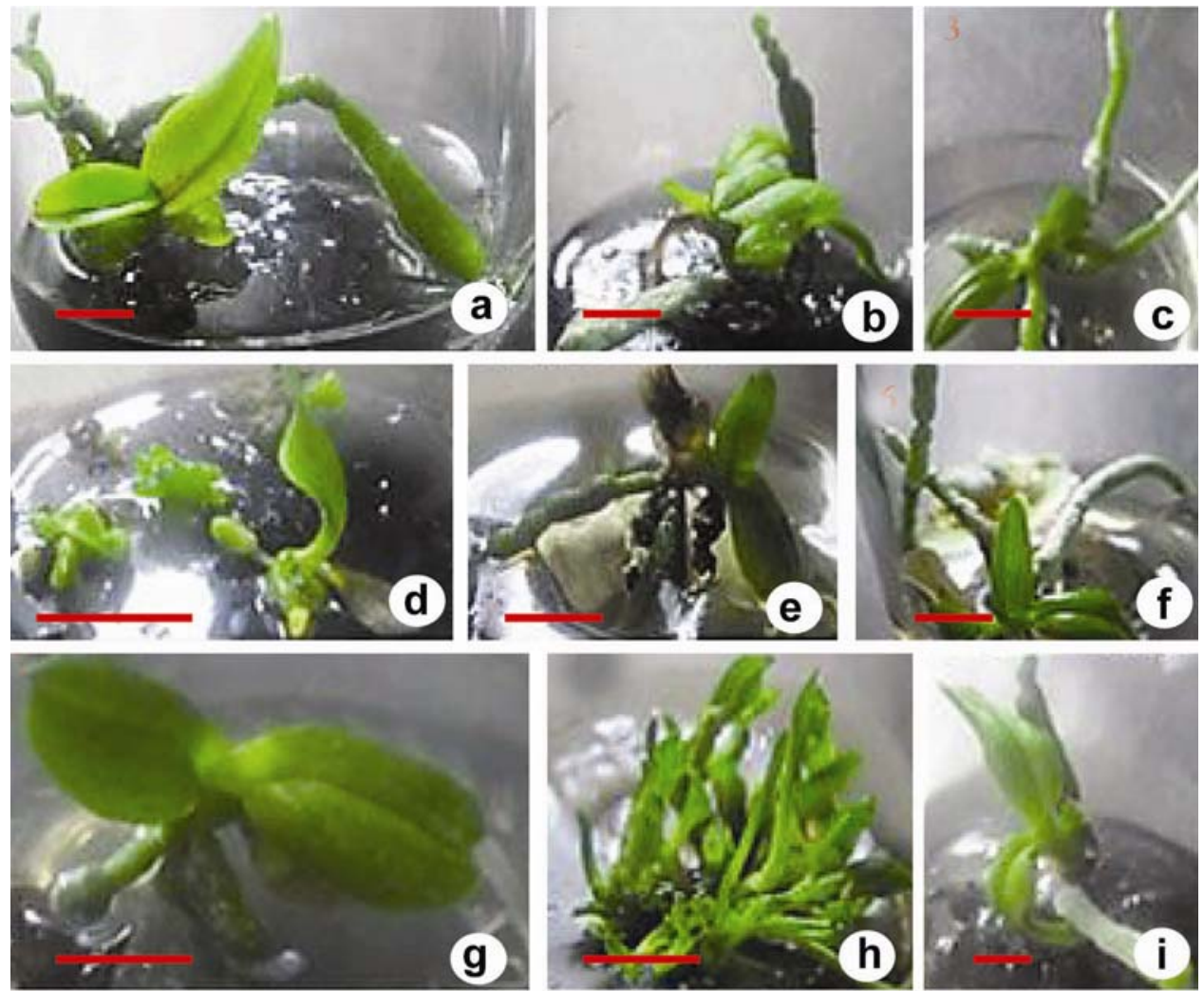

Fig. 3. Profiles of plantlet from explants of leaf base of KNAT1 transformant at 15 weeks after planting. Plantlets with roots growing upright (b, c, f and i); normal plantlets (a, e, g and h). Bar $=1 \mathrm{~cm}$. 
Figs 1 and 2 show development of explant of root base and leaf base from KNAT1 transformant planted on SIM. Fig. 3 shows profile of plantlets produced from KNAT1 transformant planted on SIM.

Vanda tricolor: Table 2 shows an average number of buds produced from explant of leaf base and shoot of WT plants and KNAT1 transformant at 6 weeks afer planting. Figure 7 shows buds produced by an explant of shoot from WT plants and KNAT1 transformant grew on SIM. Fig. 8 is an explant of leaf base from WT plant and KNAT1 transforman planted on SIM.

Table 2. The number of buds produced by each type of explant from WT plant and KNAT1 transformant at 6 weeks after planting on culture media.

\begin{tabular}{lccccc}
\hline $\begin{array}{l}\text { Types of } \\
\text { explant }\end{array}$ & \multicolumn{2}{c}{ NPO Medium } & & \multicolumn{2}{c}{ SIM } \\
\cline { 2 - 3 } \cline { 5 - 6 } \cline { 5 - 6 } Leaf base & WT & KNAT1 transformant & & WT & KNAT1 transformant \\
Shoot & 0 & 0 & & 0 & 15 \\
\hline
\end{tabular}
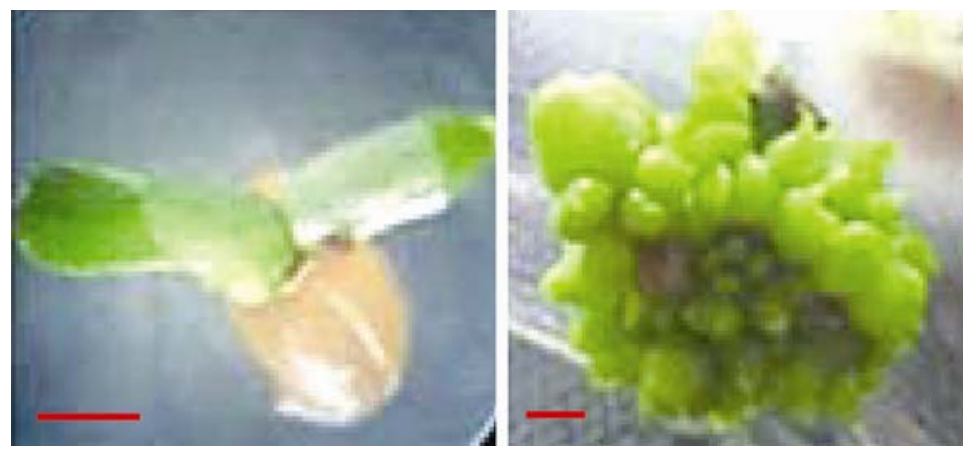

Fig. 4. An explant of shoot from WT plant (left) and KNAT1 transformant (right) at 6 weeks after planting on SIM. Bar $=1 \mathrm{~cm}$. (Source: Dwiyani 2012).

There are several points can be taken into account from this present study. Results of both experiment on $P$. amabilis and $V$. tricolor indicated that the role of KNAT1 gene in keeping plant cells under 'meristematic state' was still work functionally on the organ of transformant plant. The number of shoots produced by explants from transformants were much higher compared to WT plants, indicating its ability to regenerate was higher. Micropropagation of organ of transformant plants showed formation of propagules which grew and developed to be buds and then regenerated to be plantlets. We assumed that with constitutive promoter of 35SCaMV, KNAT1 gene expressed in the organ of transformant, keeping cells in the 'meristematic state' (like at the SAM) as they easily regenerated and formed buds. The result was in conformity with Frugris et 
al. (2001) who found that KNAT1-transformed callus of Lactuca sativa regenerate faster compared to those of non transformed callus when they planted on the same medium for regeneration. Semiarti et al. (2007) also found that KNAT1transformed protocorms of $P$. amabilis orchid showed phenotype of multi shoots up to 35 shoots, while the WT produced only 1 to 3 shoots.

In the current research, cytokinin application as shoot-promoting hormones was still required to promote formation of buds on organ of transformant plant, although Yanal et al. (2005) proposed that KNOX protein in A. thaliana promotes biosynthesis of indegenous cytokinin of plants. The role of cytokinin for shoot inducing in micropropagation was reported elsewhere. In the current research, application of cytokinin such as 2-iP might change the status of undeterminate state of those meristematic cells in the organ to be determinate state, so they formed buds, roots and then grew to be plantlets.

Type of explant of leaf base, shoot and root base produced buds in the higher number compared to other type of explants. In this case, we proposed that accumulation of indigenous hormones and might also accumulation of photosyntate (products of photosynthesis) was higher in these part of plant. However, it still needs further research to prove this statement.

There was morphologically variation on the plantlets produced (in $P$. amabilis), although normal seedlings were used as source of explant, indicated somaclonal variation occurred (Fig. 3).

Detection of transgene in these somaclones was also done with limited samples as can be seen in Fig. 5 .



Fig. 5. Electroforegram of PCR results of some somaclones propagated from P. amabilis orchid carrying KNAT1 gene. Somaclones from explant of leaf base $(1 \mathrm{a}, \mathrm{b})$; root base $(2 \mathrm{a}, \mathrm{b})$; and shoot (3a). $\mathrm{M}$ is molecular marka, $\mathrm{A}$ is WT plant. Band of $1,2 \mathrm{~kb}$ indicated of KNAT1 gene. 
Specific primer for KNAT1 gene (Semiarti et al. 2007, Dwiyani 2012) was used. We found the transgene was still integrated in the genome of some samples, indicated that the transgene was inherited in to some progenies of plants which were propagated with in vitro culture.

\section{Conclusion}

We concluded three point from the results of this research. First, cells of KNAT1 transformant were more meristematic compared to wild type plants as the organ produced more buds in micropropagation. The second, there were some various phenotypes found in progenies of plantlets produced from KNAT1 transformant. The third, KNAT1 gene was still detected in some progenies propagated with in vitro culture.

\section{References}

Barton MK (2001) Leaving the meristem behind : regulation of KNOX genes. Genome Biol. 2(1): Reviews:10021-10023.

Bharathan G, Jansen BJ, Kellogg EA, and Sinha N (1999) Phylogenetic relationships and evolution of the KNOTTED class of plant homeodomain proteins. Mol. Biol. Evol. 16: 553-563.

Dwiyani R (2012) Micropropagation of Vanda tricolor Orchid Carrying KNAT1(KNOTTED1-LIKE Arabidopsis thaliana) Gene (In Indonesian). Disertation. Gadjah Mada University, Indonesia.

Frugis G, Giannino D, Mele G, Nicolodi C, Innocenti AM, Chiappetta A, Bitonti MB, Dewitte W, Van Oncklen H and Mariotti D (1999) Are homeobox knotted-like genes and cytokikins the leaf architects? Plant Physiology 119: 371-373.

Islam MO, Ichihasi S and Matsui S (1998) Control of growth and development of protocorm like body derived from callus by carbon sources in Phalaenopsis. Plant Biotechnol. 15: 183-187.

Isminingsih S (2004) Transformation of KNAT1(KNOTTED1-LIKE Arabidopsis thaliana) gene on Phalaenopsis amabilis orchid (In Indonesian). Thesis. Gadjah Mada University, Indonesia.

Reiser L, Sanchez-Baracaldo P and Hake S (2000) KNOTTS in the family tree : Evolutionary retionships and functions of KNOX HOMEOBOX genes. Plant. Mol. Biol. 42: 151-166

Scofield S, Dewitte W and Murray JAH (2008) A model for Arabidopsis class-1 KNOX gene function. Plant Signal Behav. 3: 251-259.

Semiarti E, Indrianto A, Purwantoro A, Isminingsih S, Suseno N, Ishikawa NT, Yoshioka Y, Machida Y and Machida C (2007) Agrobacterium-mediated transformation of the wild orchid species Phalaenopsis amabilis. Plant Biotechnol. 24 : 265-272. 
Semiarti E, Ueno Y, Tsukaya H, Iwakawa H, Machida C and Machida Y (2001) The ASYMMETRIC LEAVES2 gene of Arabidopsis thaliana regulates formation of a symmetric lamina, establishment of venation and repression of meristem-related homeobox genes in leaves. Development 128: 1771-1783

Yanal O, Shani E, Dolezal K, Tarkowski P, Sablowski R, Sanberg G, Samach A and Ori N (2005) Arabidopsis KNOX proteins activate cytokinin biosynthesis. Curr. Biol. 15: 1566-1571. 